\title{
Bone Cancer Clinical TNM Finding v7
}

National Cancer Institute

\section{Source}

National Cancer Institute. Bone Cancer Clinical TNM Finding v7. NCI Thesaurus. Code C88443.

A clinical finding about one or more characteristics of bone cancer, following the rules of the TNM AJCC v7 classification system. The clinical staging includes all relevant data prior to primary definitive therapy, including physical examination, imaging, and biopsy. (from AJCC 7th Ed.) 